ROMAN SOBOTKA (Warszawa)

\title{
O mediewistycznej twórczości Juliusza Bardacha
}

W dniu 26 stycznia 2010 zmarł w wieku 95 lat Juliusz Bardach, zaliczany do grona najwybitniejszych historyków prawa XX w. Autor niniejszych słów przez wiele lat brał udział w Jego seminarium, pisał pod Jego kierunkiem i opieką pracę magisterską i doktorską. Sposób uprawiania nauki przez Profesora i podejście do drugiego człowieka odciskały niezatarte piętno na Jego uczniach, do których grona autor też ośmiela się zaliczać. Poniższy tekst ukazuje mediewistyczne wątki prac Juliusza Bardacha ${ }^{1}$. Autor pragnąłby także, aby był to hołd oddany wielkiemu Uczonemu i Człowiekowi.

Od początku swej drogi naukowej Juliusz Bardach związany był z badaniami nad historią prawa litewskiego. Dosyć szybko swe zainteresowania rozszerzył też na Koronę. W wieku 38 lat $^{2}$ napisał pierwszy szkic monumentalnej syntezy dziejów państwa i prawa polskiego. Po skrypcie opublikował - kolejno - wersję podręcznikową, która z czasem stała się - w wersji rozszerzonej - pierwszym tomem pięciotomowej syntezy obejmującej historię ustroju i prawa do 1939 r. J. Bardach był nie tylko autorem części obejmującej okres do połowy $\mathrm{XV} \mathrm{w.}{ }^{3}$, ale także redaktorem całości. Na bazie tej wielotomowej syntezy wydano w 1976 r. podręcznik akademicki dla studentów pra-

${ }^{1} \mathrm{Z}$ prac poświęconych dorobkowi Juliusza Bardacha warto wskazać na artykuły Marka Wąsowicza, Kultura prawna w dorobku Profesora Juliusza Bardacha, [w:] Z dziejów kultury prawnej. Studia ofiarowane profesorowi Juliuszowi Bardachowi w dziewięćdziesięciolecie urodzin, kom. red. A. Rosner et al., Warszawa 2004, s. 11-17; Stanisława Grodziskiego, Historyzm prawniczy Juliusza Bardacha, CPH T. 62: 2010 z. 2 s. 11-18 oraz Henryka Olszewskiego, Między Themis a Clio: Spojrzenie na warsztat naukowy Juliusza Bardacha, [w:] W poszukiwaniu dobra wspólnego. Ksiega jubileuszowa profesora Macieja Zielińskiego, red. A. Choduń i S. Czepita, Szczecin 2010, s. 949$-963$.

${ }^{2}$ Historia państwa i prawa polskiego, skrypt, Warszawa 1952.

${ }^{3}$ W latach 1957-1973 tom ten miał 4 wydania, ciągle poprawiane i uzupełniane, Historia państwa i prawa Polski. Tom I do połowy XV wieku (dalej: HPiPP). Obok recenzji historyków prawa zamieszczonych w T. 10 CPH (A. Vetulani, s. 307-345; K. Koranyi, s. 347-359 i in., s. 361-373 i odpowiedź J. Bardacha, s. 375-415) zob. też obszerną recenzję pióra K. Tymienieckiego, Polskie państwo feudalne, „Kwartalnik Historyczny” (dalej KH) 65: 1958 nr 3 s. 825-843. Recenzent, pomimo uwag polemicznych, zakończył: „nie ma opuszczeń, a są za to nowe interesujące rozdziały 
wa i administracji ${ }^{4}$, który w 1993 r. gruntownie przepracowano ${ }^{5}$. Tak więc dzieło w poprawianej wersji (a widać to w przypisach wielu artykułów) służy badaczom i studentom już sześćdziesiąt lat.

Nie miejsce tu, by omawiać tę wielką syntezę. Warto jednak zwrócić uwagę na kilka zagadnień z nią związanych. Po pierwsze: była to pierwsza synteza obejmująca łącznie historię ustroju państwowego i prawa prywatnego. Po drugie: jej cechą charakterystyczną jest to, że bazuje przede wszystkim na interpretacji źródeł, których teksty bardzo licznie przywołuje w przypisach. Czytelnik może od razu, nie odrywając się od tekstu zasadniczego, sprawdzić poprawność wywodu i wyrobić sobie własną opinię. Nie musi więc opierać się tylko na interpretacji dokonanej przez autora. Ten szacunek dla inteligentnego, znającego łacinę, czytelnika i jednocześnie brak autorytatywnego narzucania własnej wizji był cechą charakterystyczną twórczości Juliusza Bardacha. Piszący te słowa słyszał wielokroć na seminarium u Profesora, padające z Jego ust: stwierdzenie „kto ma rację - oceni historia”, przedstawiał bowiem zawsze punkty widzenia swoich oponentów. To podejście expressis verbis przedstawił też $\mathrm{w}$ jednym $\mathrm{z}$ tekstów, pisząc: „wartość tego, co znalazłem oceni - jak zawsze - czytelnik" .

W syntezie, którą nazwać można opus magnum Juliusza Bardacha, skupiają się zasadnicze wątki Jego zainteresowań: slawistyka, studia nad parlamentaryzmem, organizacją państwa, władzą publiczną i samorządem, historią myśli historycznoprawnej. Niektóre z nich rozwijał później w osobnych studiach, a czasem nawet seriach artykułów. Tak - na przykład - było w przypadku wywodów o państwie wczesnośredniowiecznym w Polsce.

W syntezie historii Polski i w artykułach, które powstały w związku z obchodami milenijnymi dużo miejsca poświęcił ewolucyjnemu kształtowaniu się państwowości polskiej: od ustroju rodowo-plemiennego przez wspólnotę terytorialną (opartą na więzi sąsiedzkiej, z dominującym opolem) do państw plemiennych, z których połączenia (podboju) wyłoniła się Polska. Wizja ta zbieżna była z tą, którą później przedstawił w Początkach Polski Henryk Łowmiański. Warto dodać, że wiele lat później profesor Bardach zdystansował się od niej, zauważając, że w takim opisie „dziejów wczesnośredniowiecznych dominowały z góry przyjęte założenia, do których dopasowywano faktograficzną egzemplifikację"7.

poświęcone oderwanym ziemiom polskim na zachodzie. Wszędzie wypada stwierdzić to samo opanowanie przedmiotu, pełnię informacji i dobre przemyślenie konstrukcji całości”.

${ }^{4}$ J. Bardach, B. Leśnodorski, M. Pietrzak, Historia państwa i prawa polskiego, Warszawa 1976.

${ }^{5}$ J. Bardach, B. Leśnodorski, M. Pietrzak, Historia ustroju i prawa polskiego, Warszawa 1993. W 2009 r. ukazało się kolejne unowocześnione, poprawione i częściowo przeredagowane wydanie.

${ }^{6} \mathrm{~J}$. Bardach, Kara ,trzysta” i oplata , trzeszne” w najdawniejszym prawie polskim, CPH T. 18: 1966 z. 1 s. 48.

${ }^{7}$ W recenzji S. Gawlasa, O kształt zjednoczonego Królestwa. Niemieckie władztwo terytorialne a geneza społecznoustrojowej odrębności Polski, Warszawa 1996; J. Bardach, Model ustrojowy 
Warto też wspomnieć o poglądach Profesora na kwestię początków państwa ruskiego. Swoje przemyślenia zawarł w recenzji książki H. Łowmiańskiego o roli Normanów w budowie państw słowiańskich ${ }^{8}$. Recenzent starał się wypośrodkować między teorią normańską - podboju, a przedstawioną przez Łowmiańskiego antynormańską tezą o jedynie „pomocniczym” charakterze drużyny wareskiej i sile słowiańskiej elity możnowładczej. Zauważał, że utrzymanie się dynastii i otaczającej drużyny normańskiej byłoby niemożliwe, gdyby opierało się jedynie na sile oręża. „Interesy wspólne górowały i utrzymywały więź społeczno-polityczną między ludnością słowiańską a przybyszami ze Skandynawii" ${ }^{9}$. Do istotnych przyczyn związku rusko-wareskiego Juliusz Bardach zaliczał: minimalizowane przez Łowmiańskiego niebezpieczeństwo dla Rusinów ze strony Chazarów, Węgrów i Pieczyngów, chęć ułatwienia penetracji handlowej i militarnej na teren ziem Cesarstwa Bizantyjskiego i dążenie do rozszerzenia panowania Kijowa na inne organizacje polityczne Słowian wschodnich.

Można powiedzieć, że znaczna część twórczości Profesora z lat pięćdziesiątych i sześćdziesiątych była de huius rei publice origine, progressu et consummatione $^{10}$. W artykułach tych zauważał, że jedność i ciągłość polskiego procesu historycznego oparły się na trwałych podstawach uformowanych przez państwowość polską X-XI w. Podkreślał twórczą, dynamiczną rolę państwa zarówno w przemianach natury ideologicznej (wprowadzenie chrześcijaństwa), jak i w zasadniczych zjawiskach gospodarczych i społecznych ${ }^{11}$. Państwo stanowiło wówczas potężny czynnik rozwoju ${ }^{12}$. Jak bowiem zauważył: to nie możni stworzyli państwo, to państwo stworzyło wielkich właścicieli $^{13}$. Szczególne zainteresowanie początkami państwa polskiego Profesor uzasadnił tym, że to one określiły w znacznej mierze dalszą historię narodu polskiego ${ }^{14}$. Bardzo pozytywnie oceniał też siłę państwa wczesnośredniowiecznego. Poświęcał mu (jego organizacji, przemianom, znaczeniu) dużo miejsca w swych pracach - jak na historyka ustroju przystało. Omawiał zagadnienia materialnych podstaw władzy (rozbudowany system skarbowości - danin i posług), podkreślając publiczno-prawny status tych świadczeń,

średniowiecznych Niemiec a zakres jego wpływów na Polskę XIII-XIV wieku, „Przegląd Historyczny“ (dalej: PH) 1996 z. 3 s. 609.

${ }^{8}$ J. Bardach, O roli Normanów we wczesnośredniowiecznej Stowiańszczyźnie wschodniej (na marginesie pracy H. Łowmiańskiego, Zagadnienie roli Normanów w genezie państw slowiańskich, Warszawa 1957), KH 1958 nr 2 s. 368-402.

9 J. Bardach, O roli Normanów we wczesnośredniowiecznej Słowiańszczyźnie wschodniej, s. 396.

${ }^{10}$ Kadłubek, Kronika polska, I.1.2-3, MPH n.s. T. XI, s. 6.

${ }^{11}$ J. Bardach, U podstaw polskiej państwowości. Nowe spostrzeżenia, „Państwo i Prawo” 1966 z. $4-5$ s. 624 .

${ }^{12}$ Ibidem, s. 625 .

${ }^{13}$ Ibidem, s. 617.

${ }^{14}$ J. Bardach, Państwowość polska, „Polityka” 1966 nr 3. 
co odróżniało je od renty feudalnej. Czynił to wbrew obowiązującym wtedy w doktrynie wszystkich nauk społecznych poglądom Marksa ${ }^{15}$.

Elementem siły wczesnego państwa była, zdaniem Bardacha, także organizacja kościelna, która stała się od początku istotnym elementem aparatu państwowego, a duchowieństwo wiernie na ogół realizowało politykę władcy. W swoich wczesnośredniowiecznych studiach podkreślał też niezależność Polski od cesarstwa. Odróżniał przy tym formalną wyższość (hołd lenny i zobowiązanie do trybutu) od realnego zwierzchnictwa, czyli faktycznego ograniczenia „suwerenności”16.

Profesor zauważał, że należy wystrzegać się ujęcia, według którego państwo powstało automatycznie, jako rezultat osiągnięcia odpowiedniego szczebla rozwoju sił wytwórczych. Wskazywał, że w ukształtowaniu państwa odgrywały istotną rolę i inne - społeczne i polityczne przesłanki ${ }^{17}$. Podkreślał, jak ważne dla władcy było „społeczne” zaplecze już w początkach państwa: „Siła monarchii zależała w znacznym stopniu od zakresu poparcia udzielanego monarsze przez grupy uczestniczące we władzy"18 - drużynę, aparat urzędniczy i duchowieństwo. Taka interpretacja pozytywnego stanowiska możnych wobec rodu książęcego i wynikający stąd fakt „dobrowolnego jednoczenia” ziem pod panowaniem Piastów stanowił własny wkład Bardacha w badania nad początkami państwa polskiego ${ }^{19}$.

Za Janem Adamusem ${ }^{20}$ Profesor przyjmował, że władza pierwszych Piastów była silna, ale nie absolutna. Instytucjonalnymi jej ograniczeniami było prawo oporu oraz instytucja rady książęcej i wiecu. Nie bez znaczenia był też element elekcyjny wewnątrz dynastii, obecny przy powoływaniu na tron. Wzmacniał on rolę możnowładztwa, będącego też aktywnym uczestnikiem wieców ${ }^{21}$. To pod-

${ }^{15}$ Idem, U podstaw polskiej państwowości, s. 622.

${ }^{16}$ Wedle ówczesnych pojęć, gdyż pojęcie suwerenności władzy państwowej uformowało się w początkach XIV w. i wiązało się z powstaniem państw narodowych. Zob. J. Baszkiewicz, F. Ryszka, Historia doktryn politycznych i prawnych, Warszawa 1973 s. 128; K. Grzybowski, U źródet doktryny suwerenności państwa, CPH T. 17: 1965 z. 2 s. 245; W. Ullmann, A History of Political Thought: The Middle Ages, Penguin Book 1970, s. 198-199.

${ }^{17} \mathrm{~J}$. Bardach, U podstaw polskiej państwowości, s. 609.

${ }^{18}$ Ibidem, s. 617-618.

${ }^{19}$ Zwracał na to uwagę H. Łowmiański, Problematyka początków państwa polskiego $w$ nowszych badaniach historycznych, „Slavia Antiqua” T. 22: 1976 s. 92. Warto zauważyć, że ten model jednoczenia terytoriów w państwo - oparty na współpracy - jest współcześnie kwestionowany przez Przemysława Urbańczyka, który powstanie państwa wiąże głównie z akcją militarną i uważa, że powstawało ono skokowo, a nie ewolucyjnie. P. Urbańczyk, Trudne początki Polski, Wrocław 2008 s. 217. Praca Urbańczyka spotkała się jednak z bardzo burzliwym przyjęciem wśród mediewistów, zob.: W. Duczko. KH R. 117: 2010 nr 4 s. 115-121; G. Labuda, „Roczniki Historyczne” R. 74: 2008 s. 209-231.

${ }^{20}$ J. Adamus, Problemy absolutyzmu piastowskiego, CPH T. 10: 1958 z. 2 s. 19-76.

${ }^{21}$ Zwrócił na te elementy szczególnie w artykułach, Le pouvoir, [w:] Recuils de le Societe Jean Bodin..., T. XXII: La Monocratie, Bruxelles 1969, s. 563-612, oraz La formation et les structures de l'état Polonais du X'e jusqu'au XII siècle, w: Settimane di studio del Centro italiano di studi 
kreślanie potrzeby społecznego poparcia znalazło także odbicie w uwypukleniu roli wiecu w epoce rozbicia dzielnicowego, i późniejszej roli sejmu. Zdaniem Juliusza Bardacha - panujący, w porozumieniu z wiecem, nadawał urzędy, dokonywał podziału dzielnicy między spadkobierców czy desygnował następcę. Bez zgody wiecu nie ustanawiał nowych praw, nie nakładał podatku, nie rozpoczynał wojny, nie zawierał traktatów ani małżeństwa. Na wiecu, bez udziału księcia, decydowano o ewentualnym zastosowaniu prawa oporu i dokonywano elekcji nowego władcy. Za zgodą i przy współudziale wiecu możnowładczego wydawał książę przywileje immunitetowe i lokacyjne. Bardzo duże znaczenie przyznawał Bardach działalności sądowniczej wiecu. W miarę jednoczenia państwa pojawiły się w latach 1306 i 1310 urzędnicze wiece ogólnopaństwowe, które stanowiły zapowiedź sejmu walnego ${ }^{22}$. Taka koncepcja wiecu w średniowiecznej Polsce bliska była także innemu wielkiemu znawcy słowiańskiego średniowiecza - H. Łowmiańskiemu ${ }^{23}$. W następnych latach tacy badacze jak Klaus Zernack ${ }^{24}$, Stanisław Russocki ${ }^{25}$, Piotr Boron ${ }^{26}$ przychylą się raczej do wizji wiecu związanego głównie z funkcją sądowniczą i prawodawczą. Szczególnie S. Russocki (nota bene uczeń J. Bardacha), podkreślał rolę wieców ,jako środka uzyskania posłuchu i poparcia dla decyzji władcy"27.

Problematyka sejmu staropolskiego należała do podstawowego kręgu zainteresowań Profesora. Dlatego warto szerzej przypomnieć Jego ustalenia w tym zakresie. Studia nad sejmem ugruntowały przekonanie Profesora o specyficznych cechach ustroju Polski. Gdy w Europie wzrastał absolutyzm,

„Polska z obieralnym królem o władzy silnie ograniczonej przez sejm i sejmiki ziemskie wykształciła formę rządów, którą dla drugiej połowy XV i XVI wieku określamy, jako »demokrację szlacheckąu. Początek tej nowej formy widzimy w działalności sejmików, które od statutów nieszawskich posiadały ustawowo oznaczone i istotne kompetencje prawodawcze" ${ }^{" 28}$.

sull'alto medioevo. T. 30: Gli Slavi occidentali e meridionali nell' alto medioevo, Spoleto 1983. s. 201-245.

${ }^{22}$ HPiPP I s. 250. Tę wizję szerokich kompetencji wiecu J. Bardach podtrzymywał jeszcze w Dziejach Sejmu polskiego, Warszawa 2011 s. 12 (pierwsze wydanie - 1997 r.).

${ }^{23}$ Początki Polski. T. 6, Polityczne i spoleczne procesy ksztaltowania się narodu do poczatku wieku XIV, cz. 1, Warszawa 1985 s. 222 n.; Problematyka początków państwa polskiego w nowszych badaniach historycznych, „Slavia Antiqua” T. 22: 1976 s. 86 n.

${ }^{24} \mathrm{~K}$. Zernack, Burgstädtischen Volksversammlungen bei den Ost-und Westslaven, Wiesbaden 1967.

${ }^{25}$ Stowiańskie wiece i próba historycznej analizy semantyczno-funkcjonalnej. KH 83:1976 nr 3 s. 563-564.

${ }^{26}$ Stowiańskie wiece plemienne, Katowice 1999.

${ }^{27}$ J. Bardach, Stanisław Russocki o genezie parlamentaryzmu, [w:] Stanisław Russocki - badacz dziejów ustroju i prawa. W 45-lecie pracy naukowej, Warszawa 1999, s. 13-14.

${ }^{28} \mathrm{~J}$. Bardach, O genezie sejmu polskiego w Pamiętnik VIII Powszechnego Zjazdu Historyków Polskich w Krakowie 14-17 września 1958 r., Referaty cz. 2, Warszawa 1958, s. 521. Zob.: pozytywna recenzja G. Labudy, RH T. 27: 1961 s. 275-76. 
Znaczenie, jakie Juliusz Bardach przykładał do 1454 r. ${ }^{29}$ i terminu ,demokracja szlachecka" ${ }^{30}$, która wtedy to miała się narodzić, miało ogromny wpływ na periodyzację syntez państwa i prawa polskiego powstałych pod Jego redakcją. Do dziś - w znacznej mierze dzięki autorytetowi naukowemu Profesora - są przyjmowane w podręcznikach. Dzięki swoim badaniom komparatystycznym zwracał uwagę na to, że sejm polski był takim samym zgromadzeniem stanowym jak te występujące w innych krajach europejskich $^{31}$.

W artykule $O$ genezie sejmu polskiego Bardach przeciwstawiał się stanowisku Stanisława Kutrzeby, wedle którego sejm miał powstać w końcu XV w. Juliusz Bardach pierwotnie uważał, że Rada królewska nie była jądrem krystalizacyjnym sejmu ${ }^{32}$. Same zaś sejmy wywodził ze zjazdów ogólnopaństwowych, które - znowu - powstały z wieców epoki rozbicia dzielnicowego. Sejmy powstały więc wskutek rozszerzenia składu społecznego zjazdów o przedstawicieli miast i kapituł. Ten szeroki skład sejmów podkreślały ich nazwy: conventio magnum, conventio solemnum, parlamentum. W takich zjazdach Profesor wyróżniał trzy grupy: możnowładcy z rady królewskiej, niższa szlachta urzędnicza oraz reszta szlachty z przedstawicielami miast i kapituł diecezjalnych. Tej ostatniej grupie, określanej jako communitas nobilium, doraźnie udawało się wywrzeć wpływ na możnowładców. To określenie ogółu szlachty świadczyło, według Juliusza Bardacha, o wyodrębnieniu się w „osobną od urzędniczego możnowładztwa grupę posiadającą samowiedzę odrębności swoich interesów i stanowiącą określone pojęcie prawne"33. W kwestii genezy sejmu - pod wpływem badań Stanisława Russockiego zmienił później zdanie i napisał, że ukształtował się on z plenarnej rady królewskiej, obok której zbierał się ogół szlachty ${ }^{34}$.

Poważną trudnością w badaniach początków sejmu było, zdaniem Bardacha, pomijanie przez Długosza informacji o aktywności politycznej szlachty. Miało to wynikać z tarć między aktywną politycznie szlachtą nieurzędniczą a duchowieństwem. Cechą charakterystyczną sejmu w XV w. wedle Juliu-

${ }^{29}$ Pisał, że nie dość jest podkreślać wagę przywilejów nieszawskich dla rozwoju parlamentaryzmu, J. Bardach, O genezie sejmu polskiego, s. 534.

${ }^{30}$ Naukowości tego określenia bronił, O genezie sejmu polskiego, $521 \mathrm{n}$.

${ }^{31}$ Ibidem, s. 525.

${ }^{32}$ Ibidem, s. 526.

${ }^{33}$ Ibidem, s. 528.

${ }^{34}$ Historia sejmu polskiego, pod red. J. Michalskiego, T. 1: Do schyłku szlacheckiej Rzeczypospolitej, Warszawa 1984 (dalej: Do schytku) s. 9. Stanowisko to podtrzymał i w nowszej syntezie Dzieje Sejmu polskiego, koordynator pracy J. Bardach, wyd. 3, Warszawa 2011, s. 13. Jednocześnie cały czas przyjmował szerokie kompetencje wiecu w epoce rozbicia dzielnicowego (zob. tamże s. 12). Przez przeoczenie chyba, wersja wywodząca sejm z wieców (zjazdów) pozostała jednak w popularnym podręczniku, J. Bardach, B. Leśnodorski, M. Pietrzak, Historia ustroju i prawa polskiego, wyd. 5, Warszawa 2003, s. 104. 
sza Bardacha była alternatywność zgromadzeń, tj. ogólnopaństwowego sejmu walnego, sejmów prowincjonalnych (wielkopolskiego i małopolskiego, zwanych generalnymi) i sejmików ziemskich. Zamienne funkcjonowanie tych zgromadzeń, wyposażonych w funkcję prawodawczą, było możliwe w warunkach utrzymywania się odrębności lokalnych i stanowiło polską specyfikę. Do różnic prowincjonalnych zaliczał większą rolę średniej szlachty w Wielkopolsce, a możnowładztwa - w Małopolsce. Wspieranie wspólnot regionalnych leżało $\mathrm{w}$ interesie króla, który w ten mógł wygrywać poparcie jednych przeciw innym. Tak więc można zauważyć pewną tendencję: osłabienia władzy monarszej i jednocześnie wzrostu znaczenia możnowładztwa oraz sejmu walnego w pierwszej połowie XV w., a umocnienia władzy króla. Temu towarzyszył wzrost roli sejmików w drugiej połowie XV w. Jak zauważał Profesor - ta tendencja z czasów Kazimierza Jagiellończyka, występowała też współcześnie we Francji, której królowie preferowali stany prowincjonalne w przeciwieństwie do generalnych ${ }^{35}$.

Dostrzegając odrębności lokalne, Bardach nie zwrócił uwagi na różnice w tekstach przywilejów nieszawskich wydawanych dla poszczególnych ziem - choć znał pracę Stanisława Romana o przywilejach nieszawskich. Omawiając dokładnie dwa artykuły przywileju cerekwickiego (o zniesieniu nowych ceł oraz o uprzedniej zgodzie wspólnoty ziemskiej na zwołanie pospolitego ruszenia i stanowienie nowych praw), odnosił je do całego państwa, choć S. Roman ustalił, że przywilej w Cerekwicy (wydany dla Wielkopolski), zastąpiono później nową wersją przywileju nieszawskiego ${ }^{36}$, w którym wspomniany artykuł wspomina wyraźnie tylko o zwołaniu sejmiku w Środzie (convencione communi terrestri in Srzoda) ${ }^{37}$. Mimo że później zauważał różnice lokalne, zasadniczo - podtrzymywał jednak swą ocenę znaczenia rozwiązań z $1454 \mathrm{r}^{38}$ Między innymi nadawał trwałe znaczenie artykułowi przywileju korczyńskiego dla Małopolski z 1456 r. o zgodzie sejmu prowincjonalnego na zwołanie pospolitego ruszenia $\mathrm{z}$ tej prowincji, choć sam zauważał, że miał obowiązywać w czasie wojny z Zakonem.

Według Juliusza Bardacha, bezkrólewia i elekcje królów umacniały rolę sejmu walnego i jednocześnie wzmacniały, wyrażoną w idei Korony Królestwa Polskiego, koncepcję publiczno-prawną państwa i jego jednolitośćc ${ }^{39}$. Z ciągłymi zabiegami Jagiełły o sukcesję tronu dla synów wiązał on uzyska-

${ }^{35} \mathrm{~J}$. Bardach, O genezie sejmu polskiego, s. $529 \mathrm{n}$.

${ }^{36}$ S. Roman, Przywileje nieszawskie, Warszawa 1957, s. 191.

${ }^{37}$ Archiwum Komisji Prawniczej AU, T. V, Kraków 1897, s. 68.

${ }^{38}$ J. Bardach, Do schyłku, s. 32-35. Obecnie wydaje się jednak, że rozwiązania przyjęte w tekście przywileju nieszawskiego dla Wielkopolski nie weszły w życie, więc trudno nadawać dacie jego wydania przełomowe znaczenie, zob. R. Sobotka, Między monarchiq stanowa a demokracja szlachecką. Znaczenie przywilejów nieszawskich w periodyzacji dziejów Polski, „Zeszyty Prawnicze" [UKSW] R. 11 z. 4: 2011 s. 67-101.

${ }^{39} \mathrm{~J}$. Bardach, O genezie sejmu polskiego, s. 530-1. 
nie lepszych warunków do rozwoju sejmików i sejmu ${ }^{40}$. Jego zdaniem też - kompetencje sejmu zależały od sytuacji faktycznej, na którą wpływ miały głównie aktualne potrzeby króla. Istotne znaczenie miało zezwalanie stanów na podatki, jednak Profesor nie upatrywał w nim genezy parlamentaryzmu, gdyż kwestie podatkowe wysunęły się na czoło dopiero w drugiej połowie XV w. W pierwszej połowie tego wieku sejm był forum zabiegów króla o poparcie panów i szlachty dla jego polityki. Istotne też było rozwijanie przez sejmy prawa sądowego i państwowego ${ }^{41}$. Do spraw podatkowych i ich znaczenia dla rozwoju sejmu J. Bardach wrócił w późniejszych pracach, podtrzymując generalnie swoje wcześniejsze stanowisko ${ }^{42}$.

Wiele miejsca poświęcił pozycji szlachty w systemie władzy w XV w. Zauważał spory szlachty z duchowieństwem. Wpływom husytyzmu przypisywał konfederacje lat 1438 i 1439, które - Jego zdaniem - podkreślały odrębność interesów szlachty. W wydzieleniu się reprezentacji szlachty w odrębną izbę widział przejaw jej emancypacji, jednak nie oznaczało ono - wbrew Witoldowi Knoppkowi ${ }^{43}$ - zwycięstwa w walce z możnowładztwem ${ }^{44}$. Dużo miejsca poświęcił teorii reprezentacji, podnosząc, za Johnem Gilissenem, że wynikać mogła ona nie tylko z wyboru, ale reprezentanci mogli być też delegowani czy losowani. Odnosząc to do Polski, postulował kolejne badania mające na celu wyjaśnienie problemu, w jakim stopniu reprezentantami byli niżsi urzędnicy ziemscy ${ }^{45}$. W świetle dzisiejszej wiedzy wydaje się, że Juliusz Bardach zbyt idealistycznie traktował wspólnotę szlachecką w XV w. Nie zauważał roli związków rodowych w pierwszej połowie XV w. ${ }^{46}$ Przeciwstawiał sobie, chyba nazbyt pochopnie, możnych i resztę szlachty.

W rozwoju sejmu za Kazimierza Jagiellończyka i udziale wspólnoty szlacheckiej w sprawowaniu władzy widział trwałą tendencję rozwojową ${ }^{47}$, która doprowadziła do rozkwitu parlamentaryzmu w XVI stuleciu. Nie zgadzał

${ }^{40} \mathrm{~J}$. Bardach, O stawaniu się sejmu polskiego we wspótczesnej historiografii, [w:] Parlamentaryzm w Polsce we współczesnej historiografii, red. J. Bardach, Warszawa 1995, s. 31.

${ }^{41} \mathrm{~J}$. Bardach, O genezie sejmu polskiego, s. 532.

42 J. Bardach, O stawaniu się sejmu polskiego we wspótczesnej historiografii, s. 36-9. O związku podatków z kształtowaniem się sejmu poświęcił swe obszerne studium: La formation des Assemblées polonaises au XV siècle et la taxation, [w:] Anciens Pays et Assemblées d'États, Bruxelles 1970 , t. 70 s. 251-296.

${ }^{43}$ W. Knoppek, Zmiany w uktadzie sit politycznych $w$ Polsce $w$ drugiej polowie XV w. i ich zwiazek z geneza dwuizbowego parlamentu, CPH T. 7: 1955 z. 2, s. 55-98.

44 „Przemiana powszechnego zgromadzenia stanowego w reprezentacyjny parlament stanowy odbywała się z przerwami i nawrotami”, J. Bardach, O genezie sejmu polskiego, s. 536.

45 Ibidem, s. 538.

46 J. Wiesiołowski, Kultura szlachecka, w: Kultura Polski średniowiecznej XIV-XV w., red. B. Geremek, Warszawa 1997 s. 172. W I poł. XV w. mamy do czynienia z reprezentacją nie ziemską, a - rodów heraldycznych, zob. M. Koczerska, Composicio clenodiorum - fikcyjna konfederacja, w: Parlament, prawo, ludzie. Studia ofiarowane prof. Juliuszowi Bardachowi w sześćdziesięciolecie pracy twórczej, Warszawa 1996, s. 108.

${ }^{47} \mathrm{~J}$. Bardach, O genezie sejmu polskiego, s. 539. 
się tym samym $\mathrm{z}$ historykami, którzy $\mathrm{w}$ rządach młodszego syna Jagiełły widzieli tendencje protoabsolutystyczne ${ }^{48}$. Swoje stanowisko podtrzymywał w późniejszych pracach, w których też dokładnie je uzasadnił ${ }^{49}$. W badaniach nad kształtowaniem się sejmu podkreślał wpływ węgierskiego parlamentary$\mathrm{zmu}^{50}$. Choć był zwolennikiem ewolucyjnego podejścia do badań nad genezą sejmu, to doceniał rolę podejścia instytucjonalnego i wskazywał, że oba się uzupełniają ${ }^{51}$. W późniejszych latach podkreślał też znaczenie konfederacji dla rozwoju parlamentaryzmu w XV w. ${ }^{52}$

Kolejnym istotnym problemem badawczym, którym zajmował się Bardach, była kwestia swoistości feudalizmu w ustroju państwa polskiego ${ }^{53}$. $\mathrm{Z}$ jednej strony - feudalizm dla niego to „system stosunków produkcji oparty na wyzysku chłopstwa przez panów gruntowych skupiających w swoich rękach własność podstawowego środka produkcji - ziemi”. Odróżniał tak pojmowany feudalizm (ten termin stosował przy opisie sytuacji w Polsce) od feudalizmu jako systemu społeczno-politycznego opartego na hierarchicznej zależności (feudalizm lenny), który - według Profesora - nie rozwinął się w Polsce na szerszą skalę. Pomimo to odnajdywał on wiele elementów feudalizmu lennego ${ }^{54} \mathrm{~W}$ ustroju państwa wczesnośredniowiecznego ${ }^{55}$. Istotnego podobieństwa do tego ostatniego dopatrywał się Juliusz Bardach w obowiązku konnej służby wojskowej rycerzy posiadających ziemię na prawie rycerskim. Choć własność ta miała status bezwarunkowej (alodialnej), to niewywiązanie się z tego obowiązku powodowało utratę tych dóbr, co stosunki książę - rycerz upodabniało do lennych ${ }^{56}$. Jednocześnie pisał, że alodialna własność zie-

${ }^{48}$ K. Górski Rządy wewnętrzne Kazimierza Jagiellończyka w Koronie, [w:] M. Biskup, K. Górski, Kazimierz Jagiellończyk. Zbiór studiów o Polsce drugiej połowy XV wieku, Warszawa 1987, s. $122 \mathrm{n}$.

${ }^{49}$ W: Do schyłku, s. 58 n.; O stawaniu się sejmu polskiego we współczesnej historiografii, s. 33 n.

${ }^{50}$ J. Bardach, O genezie sejmu polskiego, s. 537; idem w: Do schytku, s. 9.

${ }^{51}$ J. Bardach, Do schytku, s. 12.

${ }^{52}$ Ibidem, s. 23-28.

${ }^{53}$ Współczesną dyskusję i nowe ustalenia na temat obecności w Polsce średniowiecznej feudalizmu można znaleźć w artykułach Stanisława Trawkowskiego, Spory o feudalizm w polskiej historiografii i Sławomira Gawlasa, Dlaczego w Polsce nie było feudalizmu lennego, „,Roczniki Dziejów Społecznych i Gospodarczych” T. 58: 1998, s. 91-123.

${ }^{54}$ Szereg analogii między strukturą społeczno-ustrojową w Polsce i w krajach z systemem lennym zaczerpnął J. Bardach z pracy Marcelego Handelsmana, $Z$ metodyki badań feudalizmu, w: idem, Średniowiecze polskie i powszechne, Warszawa 2010, s. 94-196. Tekst pierwotnie wydano w 1917 r. Handelsman stwierdził podobieństwa w instytucjach immunitetu, związków osobistych wewnątrz rycerstwa i powiązaniu urzędu z ziemią, która stanowiła jego uposażenie (officium-beneficium).

${ }^{55}$ Warto zwrócić uwagę, że Profesor używał często określenia „państwo wczesnośredniowieczne" obok (przeważającego wtedy w literaturze pisanej w warunkach dominacji materializmu historycznego) ,państwo wczesnofeudalne”.

${ }^{56}$ J. Bardach, B. Leśnodorski, M. Pietrzak, Historia ustroju i prawa polskiego, wyd. 5, s. 51. 
mi oraz istnienie tzw. gniazdowych ${ }^{57}$ rodów rycerskich uchroniły rycerstwo przed mediatyzacją ${ }^{58}$.

Warto zwrócić uwagę na stosunek J. Bardacha do tradycyjnie rozumianego feudalizmu zachodnioeuropejskiego, w którego funkcjonowaniu widział analogie do polskiej sytuacji społeczno-ustrojowej. To miało świadczyć o pewnym zakotwiczeniu państwa polskiego w średniowiecznej Europie, a więc - o równorzędności ustrojowej w stosunku do państw zachodnioeuropejskich $^{59}$. Tezę o rodzimej odmianie feudalizmu przeciwstawiał, błędnej jego zdaniem, teorii rodowej, której konsekwencją było uznanie „młodszości kulturalnej Polski" ${ }^{60}$. Pierwotnie w stosunku monarchy do państwa występowało, wedle J. Bardacha, łączenie władzy publicznej z własnością prywatną (zasada patrymonialna $)^{61}$. Powstała ona wskutek przeniesienia pojęć charakteryzujących stosunek pana feudalnego do jego włości ziemskiej na relację monarchy wobec terytorium państwowego. Kształtowanie się patrymonialnego stosunku władcy do państwa było także, wedle Profesora, wyrazem procesu feudalizacji ${ }^{62}$. Proces ten (który na zachodzie Europy doprowadził do wykształcenia się zwierzchnictwa terytorialnego margrabiów i hrabiów) widział też w podzielności władzy pomiędzy księcia zwierzchniego i podległych mu książąt dzielnicowych, których stanowisko odpowiadało - jego zdaniem - pozycji wasali $^{63}$. W innym miejscu napisał jednak, że we władzy księcia zwierzchniego dominował charakter publiczny ${ }^{64}$. Odnosił to, co prawda, do schyłku XI w. i nie wyjaśnił wszakże, kiedy nastąpiła zmiana w ujęciu władzy zwierzchniej (jak to określał - pryncypackiej).

Juliusz Bardach wskazywał też, że wskutek nadania immunitetów, prawa przysługujące władzy państwowej w stosunku do ludności przechodziły na instytucję kościelną lub pana świeckiego. Równolegle odbywało się przekazanie części regaliów na rzecz właścicieli dóbr. Tak więc - skutkiem było typowe dla feudalizmu przejmowanie uprawnień władzy publicznej przez osoby prywatne, powiązanie funkcji państwowych z feudalną własnością ziemi ${ }^{65}$. Typowo feudalne stosunki odnajdywał też wśród chłopów w epoce przedlokacyjnej. Wskazywał na proces popadania ludności wiejskiej w zależność od możnych świeckich i duchownych w zamian za ochronę. Twierdził nawet, że

${ }^{57}$ Łączyły one rycerzy osiadłych na jednym terenie, czasem powiązanych więzami krwi.

${ }^{58}$ HPiPP I, s. 225-226.

59 J. Bardach, Niektóre kwestie sporne w zakresie historiografii, periodyzacji i dziejów Polski wczesnofeudalnej, KH T. 63: 1956 z. 3, s. 17-18.

${ }^{60}$ Ibidem, s. 18 ,

${ }^{61}$ Tak charakter państwa wczesnośredniowiecznego ujmował już Georg Jellinek w XIX w., J. Jellinek, Ogólna nauka o państwie, Warszawa 1921, Ks. 2 s. 529.

${ }^{62}$ HPiPP I, s. 122.

${ }^{63}$ Ibidem, s. 243.

${ }^{64}$ Ibidem, s. 123.

${ }^{65}$ Ibidem, s. 180. 
działo się to w formie komendacji ${ }^{66}$. W epoce lokacyjnej jako lenne określano prawa do ziemi sołtysów i wójtów, a ich niezależna pozycja materialna i społeczna stwarzała warunki, wedle Profesora, do wyodrębnienia się tej grupy w osobny, niższy stan feudalny ${ }^{67}$.

Dziś kwestionuje się stosowanie definicji, periodyzacji, form ustrojowych, terminologii państwa, których używano w czasach, gdy pisał Juliusz Bardach. Jego jednak tezy stanowiły o kształcie dyskusji i były wówczas bardzo twórcze. Brał też aktywny udział w dyskusji na temat periodyzacji okresu średniowiecza przyjętej w sztandarowej syntezie Historii Polski, wydanej pod egidą Instytutu Historii PAN ${ }^{68}$. Był współautorem ${ }^{69}$ części pierwszej (do połowy XV w.) pierwszego tomu (do 1764 r.). Synteza ta miała 5 wydań i wielotysięczne nakłady. Pomimo współautorstwa, z czasem krytykował przyjętą tam periodyzację średniowiecza (wtedy używano określenia: „feudalizm”), zarzucając m.in. pominięcie problemu „tworzenia się i ugruntowania się stanów”70. Krytykował też schematyczne pojmowanie historii i odrzucanie faktów, pisanie wedle uproszczonej wizji: »jak być powinno«, stosując ogólne zasady materializmu historycznego w sposób mechaniczny" "71. Uważał, że należy „wskazać na błędy schematyzmu, na ujemne skutki, jakie przyniosły naszej nauce tzw. kult jednostki i podporządkowanie nauki historii bieżącym, taktycznym zadaniom agitacyjnym"72. Współcześnie wśród historyków prawa znów trwa debata o nowej periodyzacji ${ }^{73}$. Odchodzi się też obecnie od używania terminu „forma państwa"74. Współcześnie dla organizmów politycznych sprzed przełomu XIII i XIV w. rezerwuje się nazwę Królestwa (regna), nazywając ,państwem” twór postfeudalny ${ }^{75}$.

${ }^{66}$ Ibidem, s. 106.

${ }^{67}$ Ibidem, s. 396.

${ }^{68}$ Próbę częściowej oceny tej syntezy z punktu widzenia współczesnego badacza zob.: S. Kwiatkowski, Polska mediewistyka historyczna w czasach maszynopisu. O wymuszonej modernizacji i okolicznościach jej przemijania, Poznań 2010, s. 30 n. Tamże literatura.

${ }^{69}$ Napisał wspólnie z G. Labudą rozdziały: Powstanie i utrwalenie rozdrobienia feudalnego od połowy XII do połowy XIII wieku oraz Rozwój gospodarki towarowej, Narastanie tendencji zjednoczeniowych i utworzenie państwa polskiego, od połowy XIII do połowy XIV wieku.

${ }^{70}$ J. Bardach, Niektóre kwestie sporne w zakresie historiografii, s. 19-24, o stanach: s. 21.

${ }^{71}$ Ibidem, s. 15.

${ }^{72}$ Ibidem, s. 19.

${ }^{73}$ W. Uruszczak, O periodyzacji historii ustroju dawnej Polski, „Czasy Nowożytne” 12 (13): 2002.

${ }^{74}$ Idem, Formy dawnego państwa polskiego. Uwagi dyskusyjne, CPH T. 45:1993 z. 1-2 s. 407416; idem, Typologizowanie ustrojów politycznych $w$ polskiej nauce historyczno-prawnej $i$ historycznej XIX i XX w., [w:] Przez tysiąclecia: państwo-prawo-jednostka. Materiały ogólnopolskiej konferencji historyków prawa, Ustroń 17-20 września 2000 r., red. A. Lityński, M. Mikołajczyk, T. 3, Katowice 2001, s. 41-55.

${ }^{75}$ J.R. Strayer, Medieval Statecraft and the Perspectives of History, Princeton 1971, s. 341-348; idem, On the Medieval Origins of the Modern State, Princeton-Oxford 2005, s. 57 n.; B. Guenée, States and Rulers in Later Medieval Europe, Oxford 1985, s. 6. 
Kolejny problem ustrojowy średniowiecznej Polski, któremu Juliusz Bardach poświęcił uwagę, to podział administracyjny państwa w XIV-XV w. Swoje spostrzeżenia zawarł w recenzji pracy Antoniego Gąsiorowskiego o powiecie $^{76}$. Nie zgadzał się bowiem w pełni z etymologicznym wywodem powiatu dokonanym przez Gąsiorowskiego, który łączył tę nazwę z wiecem. Jak wskazywał recenzent, termin ,wiec” oznaczał różne instytucje. Podkreślał też wieloznaczność terminów ,powiat” i jego łacińskiego odpowiednika „,districtus". Dzięki obeznaniu w filologii słowiańskiej wykazał, że pogląd Gąsiorowskiego jest błędny, że terminu ,powiat” nie znają inne języki słowiańskie. Nie zgadzał się też ze stwierdzeniem, że ,powiat i jego dzieje wydają się być obrazem upadku władzy królewskiej i narastania wpływów szlacheckich na najniższym szczeblu, więc obrazem dezintegracji administracji monarszej", bo jak zauważał - powiat w Koronie pojawił się w dobie umacniania władzy monarszej za Kazimierza Wielkiego ${ }^{77}$. Nie zgadzał się też z tezą A. Gąsiorowskiego o osobowym charakterze organizacji powiatowej, powołując się na ustalenia A. Wolffa dotyczące districtus na Mazowszu. Nie akceptował też przeciwstawianiu przestrzennego i osobowego substratu powiatu. Uważał bowiem, że jeden nie mógł istnieć bez drugiego. Jego zdaniem powiat u schyłku XIV w. to sądowy szlachecki okręg terytorialny ${ }^{78}$. Wniosek ten był wynikiem badań porównawczych powiatu na Mazowszu, Litwie i Śląsku.

Juliusz Bardach twierdził jednak, zgadzając się tu z autorem recenzowanej pracy, że powiat funkcjonował jako jednostka terytorialna, ale nie jednostka zarządu skarbowego, choć na to wskazywać mogłyby rejestry podatkowe określające dobra, z zaznaczeniem położenia w powiecie. Wbrew A. Gąsiorowskiemu, twierdzącemu, że poborców podatkowych wyznaczał król, Juliusz Bardach wskazał źródła, w których poborców wyznaczał także sejmik, a czasem nawet - sejm. Recenzent w zasadzie zgadzał się także $\mathrm{z}$ autorem, że nie było organizacyjnych związków pomiędzy kasztelanią a powiatem. Uzupełnił ten wywód o materiał z XVI stulecia, w którym można zauważyć tendencję do uczynienia powiatu sądowego również okręgiem kasztelańskim, związanym z organizacją pospolitego ruszenia.

Po przedstawieniu niektórych ustaleń Badacza w zakresie prawa publicznego należy przejść do przedstawienia osiągnięć w zakresie koronnego prawa prywatnego. Zaliczyć można do nich ustosunkowanie się do tzw. teorii rodowej, której był przeciwnikiem ${ }^{79}$. Jako najważniejsze wskazać należy jednak

${ }^{76}$ J. Bardach, Powiat w Polsce późnośredniowiecznej, CPH T. 19: 1967 z. 2, s. 139-155, rec.: A. Gąsiorowski, Powiat w Wielkopolsce XIV-XVI wieku. Z zagadnień zarządu terytorialnego i podziałów Polski późnośredniowiecznej, Poznań 1965.

77 J. Bardach, Powiat w Polsce późnośredniowiecznej, s. 140.

${ }^{78}$ Ibidem, s. 148.

${ }^{79}$ Idem, Uwagi o ,, rodowym” ustroju spoleczeństwa i prawie bliższości w Polsce średniowiecznej, CPH T. 4: 1952 s. 407-458. (artykuł recenzyjny: K. Kolańczyk, Studia nad reliktami wspólnej 
dwa artykuły z zakresu prawa sądowego. Pierwszym z nich jest studium porównawcze wczesnośredniowiecznego prawa karnego polskiego, germańskiego i czeskiego. Zajął się w nim genezą i przemianami kary pod nazwą ,trzysta" ${ }^{80}$. "Trzysta" to nazwa najniższej kary występującej w najdawniejszym prawie zwyczajowym polskim. Nazwę jej wyjaśnił autor spisu, znanego pod nazwą Najstarszy Zwód Prawa Polskiego (dalej NZPP), pisząc, że pochodzi ona od najdawniejszego wymiaru tej kary w 300 kawałkach soli.

Autor NZPP w dwóch miejscach podał różną rzeczywistą wysokość kary w pieniądzu. W jednym artykule jest to jeden skojec lub kilka kurcząt, w innym zaś - 8 skojców dla rycerza, a 3 - dla chłopa. Zdaniem J. Bardacha, przepis z wyższą, zróżnicowaną wedle stanu, karą jest starszy, pochodzi z czasów nastania Krzyżaków w ziemi chełmińskiej. Natomiast niższa wartość odpowiada późniejszej praktyce sądowej. Zauważył on też, że bardzo często „trzysta" występowało jako forma nadzwyczajnego złagodzenia kary.

By odpowiedzieć na pytanie: czy od początku omawiana kara była najniższą i czy rzeczywiście płacono ją w kruszach soli, badacz dokonał porównawczego przeglądu norm karnych w innych prawach Europie środkowej wczesnego średniowiecza. Zwrócił uwagę na występującą często karę w wysokości 300 jednostek monety i zauważał, że to podobieństwo czysto formalne, jednak uznał, że metoda porównawcza zezwala na takie porównanie.

W szeregu szczepowych praw germańskich (choć nie we wszystkich) bardzo często występowała kara 300 solidów lub jej wielokrotność. W prawie czeskim kara 300 nummos (Bardach uznał, że chodzi o denary) występowała już statutach Brzetysława wydanych nad grobem św. Wojciecha w Gnieźnie w 1039 r. Jest to najstarsza kompozycyjna kara pieniężna na rzecz monarchy. Zdaniem Profesora wysoce prawdopodobny był związek genetyczny kary 300 nummos z systemem karnym południowogermańskich praw szczepowych. Kara 300 denarów - tak dokładnie określonych, występuje w źródłach czeskich - tzw. Statutach Konrada Oty z lat 1222-1237. Kara ta, acz książęca, występowała przede wszystkim tam, gdzie w redagowaniu przepisów prawnych uczestniczyli duchowni. To - jak uznał - przemawia za tezą o recepcji za pośrednictwem kleru tej kary do prawa czeskiego. Inne kary w statutach Konrada Oty prawdopodobnie stanowiły nowość wprowadzoną w miejsce dawnych, nieoznaczonych kar lub dla ograniczenia samopomocy. Kara 300 nummos od początku należała do kar o średnim stopniu uciążliwości. Do jej przekształcenia w karę sądową doszło w ciągu XIII w. Karę (opłatę) „trzysta” stosowano przynajmniej do przełomu XIV i XV stulecia.

własności ziemi w najdawniejszej Polsce. Rozporządzanie własnościa ziemska do końca XIV w., Poznań 1950).

${ }^{80}$ J. Bardach, Kara ,trzysta” i oplata ,trzeszne” w najdawniejszym prawie polskim, CPH T. 18: 1966 z. 1 s. $45-79$. 
W dokumentach praktyki w Małopolsce i na Pomorzu odnaleźć można karę ,trzysta”. Jej nazwa występuje zarówno po polsku, jak i po łacinie i niemiecku. Jedynie z terenu Mazowsza nie zachowały się o niej wzmianki, co jednak nie dowodzi, że jej tam nie znano. W przeciwieństwie do ziem czeskich, w Polsce kara ta występowała tylko pod nazwą „trzysta” - bez bliższego określenia, odróżniając się od innych kar kompozycyjnych. Według Juliusza Bardacha prawdopodobne było przejęcie wzoru czeskiego. Pod nazwą „trzysta” rozumiano pierwotnie w ogóle karę pieniężną. Nigdy nie była ona pobierana w wysokości nominalnej, co tłumaczyłoby skrótową nazwę i jej niewielką, nie pozostającą w żadnym stosunku do nazwy, wysokość ${ }^{81}$. Grudki soli jako namiastka pieniądza w XIII w. były reliktem, jednak pamięć o takiej praktyce mogła u autora NZPP spowodować przekonanie, że i sama nazwa, która brzmiała dlań niezrozumiale łączyła się z owymi kruszami soli. U genezy kary „trzysta” leżała - według Profesora - recepcja jej jako kary płaconej w pieniądzu kruszcowym. W praktyce XIII w. była to kara pieniężna. Sól i kurczęta stanowiły namiastkę pieniądza, ale nie leżały u podstaw tej kary ${ }^{82}$. Jako najniższa kara pozostawała w łączności z karą 6 grzywien. Stąd książęta bez specjalnych oporów rezygnowali z tych opłat. W II połowie XIII w. proces deprecjacji tych najniższych kar przybrał na sile. Kara „trzysta” nie pozostawała w stałej relacji do kary 6 grzywien.

Kara „trzysta” w Czechach i w Polsce miała charakter publiczny. Nie da się wykluczyć, że uległa ona przekształceniu i zamieniła się w inną karę (np. niestanne - najniższą karę na Mazowszu, gdzie indziej - między „trzysta” a sześć grzywien). Juliusz Bardach nie uważał, że między karami ,trzysta” i niestanne zachodzi genetyczny związek. Były to po prostu najniższe kary. „Trzysta” zaniknęła w końcu XIII w., niestanne było powszechne jeszcze w XVII w. A więc: kara „trzysta” zanikła, bo sędziom przestało się opłacać ją pobierać i została zastąpiona przez niestanne, które było trochę wyższe.

Podobna ewolucja miała miejsce w przypadku opłaty sądowej zwanej „trzeszne”, błędnie utożsamianej przez Franciszka Piekosińskiego z ,trzysta" W księstwie łęczyckim, zniesiona przez Leszka Czarnego, odrodziła się, w wyższym wymiarze, pod nazwą ,pamiętnego". Wedle Bardacha - nie ma związku etymologicznego ani rzeczowego między ,trzysta” (kara) a ,trzeszne" (opłata proceduralna na rzecz sędziów). W podsumowaniu autor stwierdził, że kara trzysta solidów w germańskich prawach szczepowych przekształcona na czeską karę trzysta denarów wreszcie na polską „trzysta” traciła na znaczeniu i ciężarze w miarę swej wędrówki na wschód ${ }^{83}$.

\footnotetext{
${ }^{81}$ Ibidem, s. 61.

${ }^{82}$ Ibidem, s. 67.

${ }^{83}$ Ibidem, s. 72.
} 
Drugi artykuł z zakresu prawa sądowego poświęcony był przemianie funkcji i nazw łacińskiej i polskiej instytucji prawidlnika ${ }^{84}$. Po raz pierwszy w źródłach nazwa ,prawidlnik” występuje w 1322 r. w dokumencie z ziemi krakowskiej. Zakres spraw, w których występował ten urzędnik, pozwala połączyć go z łacińskimi określeniami mediator i iusticiarius. Takie określenia osób pojawiają się już latach dwudziestych XIII w. w Małopolsce. Wedle ówczesnych dokumentów mediator wyznaczany był przez księcia ad hoc dla konkretnej sprawy. Do jego zadań należało: a) doprowadzenie do ugody i podział spornych dóbr (jako jednacz), b) odnowienie granic włości, oraz c) odbiór zeznania. W pierwszych dwóch przypadkach wysłannik księcia składał relację władcy, który ją zatwierdzał lub uwzględniał przy wydawaniu wyroku.

Podobnie w Wielkopolsce: najstarsza wzmianka z polską nazwą występuje w 1395 r., natomiast łaciński odpowiednik już w 1278 r. W Wielkopolsce szczególną rolę w procesie o oczyszczenie z nagany szlachectwa spełniał podkomorzy lub jego zastępca, występujący w miejsce prawidlnika. Działo się to w czasie (XV w.), gdy nazwa (i funkcja) prawidlnika zaczęła zanikać. Zdaniem Juliusza Bardacha, zbieżność między prawidlnikiem a podkomorzym, jego zastępcą lub upoważnionymi przezeń szlachcicami była całkowita. W ziemi sieradzkiej funkcją prawidlnika przejął komornik (zastępca) sędziego ziemskiego.

Najpóźniejszym i przez to najobfitszym materiałem źródłowym do poznania omawianej instytucji dysponuje Mazowsze. Już Adam Wolf zidentyfikował prawidlnika z iusticiariuszem. Najstarsze występowanie w źródłach u schyłku XIV w. w związku z procesem granicznym, wcześniejsze jest od wzmianek o podkomorzych (1444 r.). W dokumentach mazowieckich prawidlnik występuje obok woźnego, jako niższy, ale posiadający własny, odrębny charakter. Prawidlnik pobierał oddzielną (choć mniejszą) opłatę, niezależnie od podkomorzego. Prawidlnik, zawsze z woźnym, uczestniczyli w wizji na miejscu czynności prawnej, z której składali sądowi urzędową relację (rekognicję), odbierali przysięgę i przesłuchiwali świadków w postępowaniu pojednawczym, rozgraniczali dobra i asystowali przy sprzedaży nieruchomości, co iusticiarius relacjonował do ksiąg metryki. Prawidlnikiem nazywano też na Mazowszu szlachcica wysyłanego przez sąd do odbioru przysięgi od świadków szlachcica, któremu zarzucono bezprawne posługiwanie się klejnotem, gdy jego szlachectwo naganiono. W tym wypadku prawidlnik występował sam, bez woźnego. Od połowy XV w. łączono nazwę prawidlnika z osobą podkomorzego lub jego zastępcy, co można tłumaczyć recepcją rozwiązań koronnych. Postępowało równoległe zanikanie instytucji prawidlnika jako osoby wiary publicznej oraz terminologiczna identyfikacja z podkomorzym lub jego zastępcą, w zakresie spraw związanych z ustalaniem stanu faktycz-

\footnotetext{
${ }^{84}$ Idem, Prawidlnik w dawnym polskim prawie sadowym, CPH T. 21: 1969 z. 2 s. 31-67.
} 
nego w sprawach granicznych. Juliusz Bardach wykazał, że prawidlnikiem zostawał z reguły szlachcic nie piastujący urzędu.

W źródłach mazowieckich można spotkać nazwę justycjariusza nadawaną urzędnikowi o różnych od prawidlnika kompetencjach. Jest nim „oprawca”, który na Mazowszu pojawił się w II połowie XV w., kiedy zanikł już w Koronie. Iusticiariusze - oprawcy zasiadali w składzie sądu, oskarżali w sprawach karnych, przyjmowali porękę za oskarżonego.

Juliusz Bardach doszedł do wniosku, że w sądach krajów słowiańskich i (pozostających pod ich wpływem) Węgier „spotykamy w średniowieczu osoby wiary publicznej nie będące urzędnikami sądowymi”, wykonujące określone czynności prawne zlecane im każdorazowo przez sąd, któremu składały następnie sprawozdania (relacje), mające skutki prawne dla osób uczestniczących w owych czynnościach ${ }^{85}$.

Wedle ustaleń Bardacha prawidlnik to raczej funkcja (wykonywana przez różne osoby, w tym też przez podkomorzego lub jego zastępcę) a nie nazwa urzędu. Swoje zadania osoba powołana jako prawidlnik wykonywała poza miejscem odbywania sądu. Prawidlnik winien dopilnować, by czynność, której asystował, odbyła się zgodnie ze zwyczajowymi regułami postępowania. Czynnościami były wizja posiadłości lub jej granic, odbiór przysięgi w sprawach o własność. Następnie, jako osoba delegowana przez sędziego, winien zdać mu relację z czynności, w której uczestniczył. Relacja ta miała charakter urzędowy i przesądzała o wyroku końcowym.

Nie ma podstaw do identyfikowania prawidlnika z podkomorzym. W zakresie sporów granicznych Juliusz Bardach wysunął hipotezę, że monarcha zlecał swemu urzędnikowi, najczęściej podkomorzemu, zorientowanie się na miejscu w stanie faktycznym i złożenie o nim relacji. Podkomorzy występował wtedy $\mathrm{w}$ charakterze prawidlnika. $Z$ czasem rozstrzyganie sporów granicznych zaliczono do właściwych kompetencji podkomorzego. W terminologii łacińskiej można zauważyć dwie tendencje. W Małopolsce i Wielkopolsce nazwa nawiązywała do pojęcia mediatora jako, nie wchodzącej normalnie w skład sądu, osoby wyznaczonej przez władcę do polubownego załatwienia konkretnej sprawy. Juliusz Bardach zauważył, że termin ten występuje w procesie kanonicznym w znaczeniach podobnych do prawidlnika $i$ jednacza. Druga tendencja łączy się z tłumaczenia dosłownymi - iusticiarius i jego odmiany. Ten termin upowszechnił się na Mazowszu, gdzie dopiero w II połowie XV wieku nastąpiła recepcja urzędu oprawcy.

Prawidlnik nie występuje w źródłach na Rusi Halickiej. W XV w. przysięgę odbierał tam woźny sądowy. W Wielkim Księstwie Litewskim z nazwą pristawa występował w XVI w. urzędnik o odmiennych kompetencjach. Juliusz Bardach sprawdził też, czy podobny urząd występuje w prawach są-

${ }^{85}$ Ibidem, s. 58. 
siednich ludów. U Słowian południowych występował pristaw, który asystował przy czynnościach prawnych i zdawał z nich urzędową relację sądowi. Nie był nigdy urzędnikiem, powoływany był każdorazowo dla konkretnej sprawy spośród osób zaufania społecznego. Pristaw funkcjonował też na ziemiach dawnej Rusi. Pierwotnie nie był urzędnikiem książęcym, a osobą wykonującą określone funkcje sądowe na rozkaz władcy. Od XIV w. rozpoczął się proces zamiany pristawa w urząd stały, co Juliusz Bardach wiązał z krzepnięciem władzy monarszej. Na Węgrzech występował w podobnej funkcji pristaldus, która to nazwa jest zlatynizowaną formą wyrazu pristaw. Był on powoływany doraźnie, dla dokonania pewnych czynności procesowych. Wobec ustności obrotu prawnego w XI-XII w. pristaldus był świadkiem dokonania czynności, a jego oświadczenie miało charakter oficjalny. Wobec rosnącej liczby przypadków poświadczeń nieprawdy przez pristaldów, powoływanie ich poddano kontroli instytucji kościelnych. Instytucje te swymi pieczęciami uwierzytelniały dokumenty prywatne, więc $\mathrm{z}$ czasem pośrednictwo pristalda $\mathrm{w}$ poświadczaniu czynności prawnych stało się zbędne.

Na zakończenie rozważań komparatystycznych Juliusz Bardach zauważał, że ,identyczność nazw nie przesądzała [...] o identyczności pozycji i funkcji pristawa w różnych krajach słowiańskich" ${ }^{" 16}$. Prawidlnika, pristawa i pristaldusa Uczony przedstawiał jako różne odsłony osób cieszących się szacunkiem społecznym, które dzięki swej obecności przy dokonywaniu czynności prawnych czy procesowych nadawały im walor ważności lub wzmacniały ich wagę. Ewolucja prawidlnika poszła w innym kierunku niż jego odpowiedników na Rusi czy na Węgrzech. Pristaw stał się podstawowym urzędnikiem sądowym. Kompetencje pristalda dotyczące pewności obrotu prawnego, zwłaszcza nieruchomościami, przejęły instytucje kościelne.

Zanik instytucji prawidlnika Juliusz Bardach łączył z rozwojem instytucji ksiąg sądowych, które miały walor wiary publicznej. Funkcjonowanie prawidlnika było związane z ustnością procesu. Pojawienie się ksiąg doprowadziło do oczywistych zmian w zasadach procesowych. Ponieważ można było brać wypisy z ksiąg, zanikła wstecz, a relacji dokonywano bezpośrednio do ksiąg. Instytucja prawidlnika zanikała powoli $\mathrm{w}$ drodze przejmowania jego funkcji przez woźnego sądowego, który początkowo asystował prawidlnikowi. Kompetencje woźnych w Koronie w XV w zakresie wizji objęły dawny zakres mediatora-prawidlnika. Sprawy graniczne objął swoją jurysdykcją podkomorzy. Oczyszczenie z nagany szlachectwa zaczęto przeprowadzać przed kilku komisarzami, później zaś - przed sądem wiecowym lub ziemskim. W innych kategoriach spraw, gdzie świadkowie składali przysięgę przed prawidlnikiem, zaczęto ją przyjmować na forum sądu. 
Osobne studium źródłoznawcze poświęcił Juliusz Bardach ruskim przekładom polskich statutów ziemskich XIV i początku XV w. Swoje uwagi uczynił na marginesie wydanej we Wrocławiu w 1950 r. książ́ki Adama Vetulaniego i Stanisława Romana Średniowieczny ruski przekład Statutów Kazimierza Wielkiego i Władysława Jagietty ${ }^{87}$. Warto zauważyć, że przekład ten całkowicie pominął Stanisław Kutrzeba w swej monumentalnej Historii źródet dawnego prawa polskiego. Juliusz Bardach przekonująco uzasadnił podlaskie, nie zaś halickie, pochodzenie ruskiego tłumaczenia statutów $\mathrm{z}$ tzw. rękopisu nowogrodzkiego, dokonanie tłumaczenia w połowie XV w. i jego prywatny (a nie urzędowy) charakter. Następnie omówił, niewykorzystane przez obydwu badaczy, tłumaczenie statutów z tzw. rękopisu supraskiego. Datował je na lata 1454-1470, a jako thumacza wskazywał bezimiennego Czecha. Ustalenia dotyczące ruskich przekładów ziemskich statutów koronnych wiążą się, według Profesora, z dziejami recepcji prawa polskiego na Podlasiu oraz jego wprowadzeniem w ziemi chełmskiej. Wskazują one, że pomimo intensywnej kolonizacji przez żywioł polski, istniały tam około połowy XV stulecia wpływowe koła szlachty ruskiej - odbiorców tłumaczeń.

Doceniane były też opracowania J. Bardacha w zakresie historii historiografii mediewistycznej. Poza rozdziałem w syntezie ${ }^{88}$ zaliczyć tu trzeba biogramy i wspomnienia poświęcone polskim mediewistom. Najwięcej miejsca poświęcił osobie i twórczości Aleksandra Gieysztora, z którym łączyła go wieloletnia przyjaźn ${ }^{89}$. Nie można zapomnieć o recenzji prac Tadeusza Manteuffla ${ }^{90}$, wspomnieniu o Janie Adamusie ${ }^{91}$, przedstawieniu twórczości Stanisława Russockiego ${ }^{92}$ czy biogramach Stosława Łaguny, Adolfa Pawińskiego, Michała Sczanieckiego w Polskim Słowniku Biograficznym.

${ }^{87} \mathrm{~J}$. Bardach, O przekladach ruskich polskich statutów ziemskich XIV i początku XV wieku, „Studia Źródłoznawcze” 1962 s. 77-97. Uzupełniona wersja: Ruskie przekłady polskich statutów ziemskich w XIV i początku XV w., w: Studia z dziejów państwa i prawa polskiego, red. nauk. J. Matuszewski, Łódź 1999, s. 7-24.

${ }^{88}$ Podnosił to szczególnie K. Tymieniecki w recenzji powołanej w przyp. $3 \mathrm{~s} .829 \mathrm{n}$.

${ }^{89}$ J. Bardach, Aleksander Gieysztor a historia państwa i prawa, CPH T. 51:1999 z. 1-2 s. 11-36; idem, Aleksander Gieysztor a historia państwa i prawa, PH 2000 z.1 s. 3-18; idem, Aleksander Gieysztor - uczony i obywatel, „Rocznik Towarzystwa Naukowego Warszawskiego” 1999 s. 11-31; idem, Aleksandra Gieysztora wyktady historii ustroju państwa polskiego, [w:] Prawo wczoraj i dziś. Studia dedykowane profesor Katarzynie Sójce-Zielińskiej, red. G. Bałtruszajtys, Warszawa 2000, s. 33-44. Juliusz Bardach był też promotorem odnowienia doktoratu A. Gieysztora na Uniwersytecie Warszawskim w 1996 r., M. Koczerska, Aleksander Gieysztor (1916-1999), w: Mediewiści, red. J. Strzelczyk, Poznań 2011, s. 38, przyp. 27.

${ }^{90}$ J. Bardach, Tadeusz Manteuffel a historia państwa i prawa, CPH T. 29: 1977 z. 2 s. 219-226 (na marginesie książki: T. Manteuffel, Historyk wobec historii, Warszawa 1976); Tadeusz Manteuffel o historii ustroju i prawa, PH 1995 z.3-4 s. 293-301.

${ }^{91}$ J. Bardach, Jan Adamus (1896-1962). Próba charakterystyki naukowej, CPH T. 15: 1963 z. 1 s. 327-332; Jana Adamusa wspominam ..., CPH T. 49: 1997 z. 1-2 s. 163-173.

92 J. Bardach, Stanisław Russocki o genezie parlamentaryzmu, s. 11-22. 
W podejmowaniu problematyki ogólnosłowiańskiej można uznać profesora Bardacha za spadkobiercę Oswalda Balzera ${ }^{93}$. Zainteresowanie tą tematyką wyraźne jest też w monografii Wacława Aleksandra Maciejowskiego ${ }^{94}$, autora Historii prawodawstw słowiańskich, oraz w artykułach w Slowniku starożytności stowiańskich ${ }^{95}$.

Nie sposób omówić, z braku miejsca, wszystkich recenzji prac mediewistycznych napisanych przez Profesora ${ }^{96}$. Wiele $\mathrm{z}$ tych recenzji - to zmienione wersje gruntownych recenzji z przewodów habilitacyjnych, świadczących o wielkim zaangażowaniu Bardacha w naukową pomoc młodszym kolegom.

Bardzo dobra orientacja w literaturze slawistycznej, głównie rosyjskiej, prowadziła do komparatystyki, dzięki której wypełniał luki w rodzimej historiografii. Stąd pewnie tak duże zainteresowanie wczesnym średniowieczem, zwłaszcza początkami państwa polskiego, gdzie luki te były - i są - szczególnie duże i wywoływały większą potrzebę badań porównawczych.

W twórczości mediewistycznej Juliusza Bardach silne są wątki teoretyczne, zwłaszcza metodologiczne. Jak już wyżej zauważono, chętnie korzystał on $\mathrm{z}$ metody porównawczej, co widać w szeregu artykułów o początkach państwowości polskiej ${ }^{97}$ oraz w wielu recenzjach Jego pióra. Był też autorem artykułu teoretycznego o metodzie porównawczej ${ }^{98}$. Uważał jednak, że musi być ona stosowana z umiarem i przy zachowaniu należytych standardów naukowych. Materiał źródłowy dotyczący innych państw powinien znaleźć odbicie w źródłach polskich, nie wystarczy stwierdzenie podobieństwa instytucji prawa polskiego do obcej. Teza musi być poparta udowodnionymi przykładami. Przy badaniach porównawczych konieczne jest stwierdzenie możliwości recepcji i ukazanie jej dróg99. Recepcji poświęcił Bardach również osobne studia teoretyczne ${ }^{100}$.

W badaniach nad ustrojem był przeciwnikiem stosowania wyłącznie metody formalno-dogmatycznej ${ }^{101}$, której przedstawicielami byli Oswald Balzer

${ }^{93}$ Idem, Historia praw stowiańskich. Przedmiot i metody badawcze, KH $1963 \mathrm{nr} 2$ s. 255-285. Także w: J. Bardach, Themis a Clio czyli prawo a historia, Warszawa 2001, s. 147-181.

${ }^{94}$ J. Bardach, Wacław Aleksander Maciejowski i jego współcześni, Wrocław-Warszawa 1971.

${ }^{95}$ Hasła: Rada książęca, Ruska prawda, Siabr, Smerdowie, Sok, Statuty kościelne na Rusi, Traktaty międzynarodowe (Ruś), trzysta, trzesne, wspólnota terytorialna.

${ }^{96}$ Pełne ich zestawienie znajduje się w całościowej bibliografii zestawionej przez Wandę Sudnik-Bardachową, [w:] Z dziejów kultury prawnej. Studia ofiarowane profesorowi Juliuszowi Bardachowi, s. 19-68. Elektroniczna strona tej bibliografii: http://bibliografia.ihp.wpia.uw.edu.pl/biblio2.php

${ }^{97}$ W szczególności: J. Bardach, Polskie państwo wczesnopiastowskie (dorobek i perspektywy badań), KH $1960 \mathrm{nr} 4$ s. 997.

${ }^{98}$ Metoda porównawcza w zastosowaniu do powszechnej historii państwa i prawa, CPH T. 14: 1962 z.2 s. 9-57. Także w: J. Bardach, Themis a Clio czyli prawo a historia, s. 99-146.

${ }^{99}$ J. Bardach, Państwowość polska, „Polityka” $1966 \mathrm{nr} 3$.

${ }^{100}$ Recepcja w historii państwa i prawa, CPH T. 29: 1977 z. 1 s. 1-61. Także w: J. Bardach, Themis a Clio czyli prawo a historia, s. 35-97.

${ }^{101} \mathrm{O}$ metodzie naukowej J. Bardacha zob. przyp. 1. 
czy Przemysław Dąbkowski. Duży wpływ na teoretyczne poglądy Bardacha wywarł Jan Adamus - ówczesny docent USB i dyrektor Archiwum Miasta Wilna $^{102}$. Uważał więc Juliusz Bardach, że metoda badawcza powinna wiązać ,instytucje prawne i ustrojowe przemiany $\mathrm{z}$ istniejącym $\mathrm{w}$ danej rzeczywistości historycznej układem sił społecznych, ujmując je nie w izolacji, ale jako składnik życia społeczno-politycznego" ${ }^{103}$.

Z tekstów J. Bardacha przebija, jak sądzę - udana chęć wykazania, że procesy polityczno-ustrojowe w średniowiecznej Polsce nie odbiegały zbytnio od tych, które przebiegały na Zachodzie Europy. Jednakże i w epoce nowożytnej widział wielkość Rzeczypospolitej Obojga Narodów i prekursorski charakter unii polsko-litewskiej ${ }^{104}$.

Ważne prace Juliusza Bardacha tyczą społeczeństwa obywatelskiego, którego istnienie zauważał bardzo wcześnie. W wiecu widział instytucję, której podlegali władcy. Wskazywał też, że już w połowie XV w. szlachta miała wpływ na decyzje podejmowane na sejmach. Głęboki sens nadawał określeniu ,demokracja szlachecka”, uważając, że XVI wiek był najlepszym czasem Rzeczypospolitej i jej dobrze funkcjonującego systemu parlamentarnego.

$\mathrm{Z}$ pełną odpowiedzialnością można stwierdzić, że prace prof. Bardacha należą do kanonu dzieł kształtujących obraz dziejów Polski w nauce światowej i ciągle są cytowane i przywoływane w bibliografiach ${ }^{105}$, tym bardziej że wiele z nich ukazywało się w językach obcych (zarówno w Acta Poloniae Historia, jak i za granicą $\left.{ }^{106}\right)$.

Powyższy szkic jest bardzo wstępną analizą mediewistycznej twórczości Juliusza Bardacha. Badanie tej bogatej i inspirującej spuścizny jest - jak się wydaje - niezbędne.

102 J. Bardach, Jana Adamusa wspominam ..., CPH T. 49: 1997 z. 1-2 s. 163-173.

${ }^{103}$ Idem, O genezie sejmu polskiego, s. 524.

${ }^{104}$ Krewo i Lublin. Z problemów unii polsko-litewskiej, w: J. Bardach, Studia z ustroju i prawa Wielkiego Księstwa Litewskiego XIV-XVII w., Warszawa 1970, s. 11-67.

${ }^{105}$ Np. T. Ertman, Birth of the Leviathan. Building States and Regimes in Medieval and Early Modern Europe, Cambridge 1997; G. Schramm, Polska w dziejach Europy Środkowej. Studia, Poznań 2010 s. 23, przyp. 10.

${ }^{106}$ Zob. bibliografia powołana w przyp. 96. 